\title{
The halotolerance and phylogeny of cyanobacteria with tightly coiled trichomes (Spirulina Turpin) and the description of Halospirulina tapeticola gen. nov., sp. nov.
}

\author{
Ulrich Nübel,† Ferran Garcia-Pichelł and Gerard Muyzer§
}

Max-Planck-Institute for Marine Microbiology, Bremen, Germany

\author{
Author for correspondence: Ulrich Nübel. Tel: +1 406994 3412. Fax: + 14069944926. \\ e-mail: unuebel@montana.edu
}

The morphologies, halotolerances, temperature requirements, pigment compositions and 16S rRNA gene sequences of five culture collection strains and six novel isolates of cyanobacteria with helical, tightly coiled trichomes were investigated. All strains were very similar morphologically and could be assigned to the genus Spirulina (or section Euspirulina sensu Geitler), according to traditional classification. However, the isolates showed significantly different requirements for salinity and temperature, which were in accordance with their respective environmental origins. The genetic divergence among the strains investigated was large. The results indicate the drastic underestimation of the physiological and phylogenetic diversity of these cyanobacteria by the current morphology-based classification and the clear need for new taxa. Three of the isolates originated from hypersaline waters and were similar with respect to their high halotolerance, broad euryhalinity and elevated temperature tolerance. By phylogenetic analyses, they were placed in a tight monophyletic cluster apart from all other cyanobacteria. Thus it is proposed to reclassify highly halotolerant cyanobacteria with tightly coiled trichomes in Halospirulina gen. nov., with the type species Halospirulina tapeticola sp. nov.

Keywords: cyanobacteria, phylogeny, halotolerance, Halospirulina, microbial mats

\section{INTRODUCTION}

Cyanobacteria with tightly coiled trichomes are frequently found in thermal freshwater environments as well as in brackish, marine and hypersaline waters (Anagnostidis \& Golubic, 1966; Castenholz, 1977; Dubinin et al., 1995; Ehrlich \& Dor, 1985; Gabbay-Azaria \& Tel-Or, 1991; Garcia-Pichel et al., 1994; Pentecost, 1994; Tomaselli et al., 1995;

\footnotetext{
† Present address: Dept of Land Resources and Environmental Sciences, 334 Leon Johnson Hall, Montana State University, Bozeman, MT 59717, USA.

¥ Present address: Microbiology Department, Arizona State University, Tempe, AZ 85287, USA.

$\S$ Present address: Netherlands Institute for Sea Research (NIOZ), $1790 \mathrm{AB}$ Den Burg (Texel), The Netherlands.

The EMBL accession numbers for the 16S rRNA gene sequences reported in this study are $\mathrm{Y} 18789-\mathrm{Y} 18798$.
}

Wilmotte, 1991). Under favourable conditions they can form dense benthic populations and make major contributions to primary productivity (Anagnostidis \& Golubic, 1966; Castenholz, 1977; Kruschel \& Castenholz, 1998). Based on their conspicuous morphology alone, they are classified under the genus Spirulina Turpin (Anagnostidis \& Komárek, 1988; Castenholz, 1989a; Turpin, 1829; subgenus or section Euspirulina sensu Geitler, 1932). On the basis of the tightness of the helix, thin cross-walls (invisible by light microscopy) and several ultrastructural features, they are morphologically distinguished from a variety of other cyanobacteria with more loosely helical or sinuous trichomes, such as the commercially produced strains of the genus Arthrospira Stitzenberger (Anagnostidis \& Komárek, 1988; Castenholz, 1989a; Tomaselli et al., 1996). The genetic distinctness of Spirulina (strain PCC 6313) and Arthrospira (strains PCC 7345 and 8005) has been confirmed on the basis 
of 16S rRNA gene sequence analysis (Nelissen et al., 1994).

Depending on trichome diameter and coil shape, cyanobacteria of the genus Spirulina are commonly assigned to one of a few species, most frequently to Spirulina subsalsa Oersted, Spirulina labyrinthiformis Gomont and Spirulina major Kützing, regardless of their habitat of origin. Consequently, they are traditionally considered cosmopolitan micro-organisms with remarkable capabilities to acclimatize to broad ranges of environmental conditions (Anagnostidis \& Golubic, 1966; Geitler, 1932). However, morphologybased classification may provide insufficient taxonomic resolution and cyanobacteria with similar or identical morphology may have significantly different physiology. In recent years, the analysis of $16 \mathrm{~S}$ rRNA gene sequences has demonstrated that morphological groupings of cyanobacteria in some cases correspond to phylogenetically coherent taxa (Garcia-Pichel et al., 1996), whereas in others the traditional classification drastically underestimates extant diversity (Ferris et al., 1996). In bacteriology, in particular, the tolerances to and requirements for high salt concentrations and high temperatures have been recognized as important phenotypic properties correlating with phylogeny (Hiraishi \& Ueda, 1994; Imhoff \& Süling, 1996; Imhoff et al., 1998; Overmann \& Tuschak, 1997). We have demonstrated that extreme halotolerance among unicellular cyanobacteria is a physiological characteristic that can be used to define a phylogenetically coherent group of cultivated strains (Garcia-Pichel et al., 1998).

For cyanobacteria with Spirulina-like morphology, uncertainties about the evolutionary coherence of the current generic classification have been expressed sporadically on the basis of analyses of lipid compositions (Cohen \& Vonshak, 1991) or ultrastructure (Tseng \& Chang, 1990). In addition, the composition of genomic DNA in the two strains for which this information is available is quite different, with $\mathrm{G}+\mathrm{C}$ content determined to be $53.5 \mathrm{~mol} \%$ in Spirulina major PCC 6313 (Herdman et al., 1979) and $43.8 \mathrm{~mol} \%$ in Spirulina subsalsa P7 (Wilmotte et al., 1997). However, a comprehensive comparative study on the physiology and phylogeny of these cyanobacteria has been lacking and, therefore, the diversity within the botanical genus Spirulina remains largely unexplored. The question whether morphological counterparts from different environments are related or have undergone convergent evolution is particularly interesting. We have analysed and compared the 16S rRNA gene sequences, morphologies, halotolerances, temperature requirements and pigment compositions of 11 cultures of cyanobacteria currently classified as Spirulina spp., including six newly isolated strains. For three additional strains, nucleotide sequence information is available from public databases. A phylogenetic pattern emerges which is in part supported by phenotypic characteristics. We propose the reclassification at the generic level of those halotolerant, euryhaline cyano- bacteria with tightly coiled trichomes from hypersaline waters.

\section{METHODS}

Cyanobacterial strains, strain histories, cultivation and purification. Clonal strains of cyanobacteria used for this study are listed in Table 1. Freshwater medium was BG11 (Rippka et al., 1979) modified by decreasing the content of $\mathrm{NaNO}_{3}$ to $0.75 \mathrm{~g} \mathrm{l}^{-1}$. Seawater and hypersaline medium were prepared by dissolving appropriate amounts of commercial seawater salts mixture (Wiegandt) in distilled water to which nutrients, trace elements and vitamins were added according to Provasoli's Enriched Seawater formulation (Starr \& Zeikus, 1987) to half strength. The mixture was acidified with $\mathrm{HCl}$ to $\mathrm{pH} 3$ and was bubbled overnight with air to drive excess $\mathrm{CO}_{2}$ out of solution and thus reduce the amounts of carbonate and bicarbonate in the final mixture. The $\mathrm{pH}$ was then raised to $8 \cdot 2$ by addition of $\mathrm{NaOH}$ and the solution was autoclaved. This procedure prevented or minimized the formation of precipitates during autoclaving (Garcia-Pichel et al., 1998).

An axenic culture of strain CCC Baja-95 Cl. $2^{\mathrm{T}}$ was obtained after purification of filaments by repeated filtration through a nylon net (approximate mesh width $10 \mu \mathrm{m}$ ) and subsequent dilution and cultivation in hypersaline medium $(7 \%$ total salt concentration). Axenicity was controlled microscopically.

Growth rate measurements. All strains were grown in deep Petri dishes filled with liquid media of various salinities. Strain CCC Snake-P. Y-85 was incubated at $38^{\circ} \mathrm{C}$, receiving $20 \mu \mathrm{mol}$ photons of constant white light $\mathrm{m}^{-2} \mathrm{~s}^{-1}$ from fluorescent tubes for $12 \mathrm{~h}$ daily. All other cultures were incubated at $25^{\circ} \mathrm{C}$, receiving $20 \mu \mathrm{mol}$ photons of white light $\mathrm{m}^{-2} \mathrm{~s}^{-1}$ from fluorescent tubes. Growth rates were measured by non-invasively monitoring the increase with time of bulk phycobilin/chlorophyll $a$ fluorescence in the cultures using a fluorimeter specially designed for use with cultures that do not form homogeneous suspensions (Karsten et al., 1996). For each strain, the correspondence between fluorescence and biomass (dry wt) was checked $\left(R^{2} \geqslant 0.8\right.$; data not shown). Growth was followed in triplicate cultures during periods of 1-4 weeks, so that four to five doublings during exponential growth could be monitored. Linear regression analysis of the natural logarithms of the fluorescence values yielded estimates of growth rates $\left(R^{2} \geqslant 0 \cdot 85\right)$. Means and standard deviations of triplicate measurements are shown.

Determination of temperature requirements. Temperature ranges were determined by visual inspection of growth in test tube cultures with liquid media after incubation for a maximum of $43 \mathrm{~d}$. Strain CCC Snake-P. Y-85 was incubated in freshwater medium, strain S3 was incubated at a salinity of $7 \%$ and all others at a salinity of $3 \cdot 2 \%$. All strains received constant irradiance of $20 \mu \mathrm{mol}$ photons of white light $\mathrm{m}^{-2} \mathrm{~s}^{-1}$. Temperatures tested were 4, 10, 15, 20, 25, 35, 40,45 and $50^{\circ} \mathrm{C}$. Growing cultures were subjected to stepwise temperature shifts of a maximal $6^{\circ} \mathrm{C}$ each time.

Determination of carotenoid and phycobiliprotein composition. Cultures for pigment analyses were grown at salinities and light conditions as indicated for the determination of temperature requirements. Incubation temperatures were $45^{\circ} \mathrm{C}$ for strain CCC Snake-P. Y-85 and $25^{\circ} \mathrm{C}$ for all others. Carotenoid complement was determined by HPLC separation and on-line UV/visible spectroscopy. Approximately $50 \mathrm{mg}$ cells (wet wt) were extracted in acetone. 
Table 1. Strains used in this study

Strain IAM M-223 (Ishida et al., 1997; Shihira-Ishikawa, 1990) was not made available to us by the Institute of Applied Microbiology Culture Collection (University of Tokyo, Japan) despite a request.

\begin{tabular}{|c|c|c|c|c|c|}
\hline \multirow[t]{2}{*}{ Strain* } & \multirow{2}{*}{$\begin{array}{l}\text { Possible } \\
\text { classification } \dagger\end{array}$} & \multicolumn{3}{|c|}{ Origin } & \multirow[t]{2}{*}{ Reference } \\
\hline & & Site of isolation & Salinity & $\begin{array}{c}\text { Isolated } \\
\text { by : }\end{array}$ & \\
\hline $\begin{array}{l}\text { CCC Baja-95 } \\
\text { Cl. } 2^{\mathrm{T}}\end{array}$ & Spirulina subsalsa & $\begin{array}{l}\text { Pacific Ocean, salina } \\
\text { Guerrero Negro, Mexico }\end{array}$ & $16 \%$ & RWC & $\begin{array}{l}\text { This work; R. W. Castenholz, } \\
\text { personal communication }\end{array}$ \\
\hline $\begin{array}{l}\text { CCC Baja-95 } \\
\text { Cl. } 3\end{array}$ & Spirulina subsalsa & $\begin{array}{l}\text { Pacific Ocean, salina } \\
\text { Guerrero Negro, Mexico }\end{array}$ & $16 \%$ & RWC & $\begin{array}{l}\text { This work; R. W. Castenholz, } \\
\text { personal communication }\end{array}$ \\
\hline MPI S3 & Spirulina subsalsa & $\begin{array}{l}\text { Mediterranean Sea, La } \\
\text { Trinitat salt works, Spain }\end{array}$ & $10 \%$ & $\mathrm{EC}$ & $\begin{array}{l}\text { This work; E. Clavero, } \\
\text { personal communication }\end{array}$ \\
\hline MPI S1 & Spirulina labyrinthiformis & $\begin{array}{l}\text { Mediterranean Sea, La } \\
\text { Trinitat salt works, Spain }\end{array}$ & $10 \%$ & $\mathrm{EC}$ & $\begin{array}{l}\text { This work; E. Clavero, } \\
\text { personal communication }\end{array}$ \\
\hline MPI S2 & Spirulina subsalsa & $\begin{array}{l}\text { Mediterranean Sea, La } \\
\text { Trinitat salt works, Spain }\end{array}$ & $5 \cdot 7 \%$ & $\mathrm{EC}$ & $\begin{array}{l}\text { This work; E. Clavero, } \\
\text { personal communication }\end{array}$ \\
\hline MPI S4 & Spirulina subsalsa & $\begin{array}{l}\text { Mediterranean Sea, Alfacs } \\
\text { Bay, Ebro Delta, Spain }\end{array}$ & $3 \cdot 7 \%$ & $\mathrm{EC}$ & $\begin{array}{l}\text { This work; E. Clavero, } \\
\text { personal communication }\end{array}$ \\
\hline $\begin{array}{l}\text { P7 (SAG 59.90, } \\
\text { CCAP 1475/7) }\end{array}$ & Spirulina subsalsa & $\begin{array}{l}\text { Mediterranean Sea, } \\
\text { Harbour of Calvi, } \\
\text { Corsica, France }\end{array}$ & $3 \cdot 8 \%$ & AW & $\begin{array}{l}\text { Wilmotte (1991, personal } \\
\text { communication); Wilmotte } \\
\text { et al. (1997) }\end{array}$ \\
\hline UBMM Bo 89 & Spirulina subsalsa & $\begin{array}{l}\text { Baltic Sea, Boiensdorf, } \\
\text { Germany }\end{array}$ & $1.5 \%$ & $\mathrm{JR}$ & Rethmeier (1995) \\
\hline UBMM Hi 45 & Spirulina major & $\begin{array}{l}\text { Baltic Sea, Hiddensee, } \\
\text { Germany }\end{array}$ & $1.0 \%$ & JR & Rethmeier (1995) \\
\hline $\begin{array}{l}\text { PCC } 6313 \\
(\text { ATCC 29542) }\end{array}$ & Spirulina major & $\begin{array}{l}\text { Pacific Ocean, Berkeley, } \\
\text { USA }\end{array}$ & Brackish & MMA & $\begin{array}{l}\text { Rippka et al. (1979); Rippka } \\
\text { \& Herdman (1992) }\end{array}$ \\
\hline $\begin{array}{l}\text { CCC Snake } \\
\text { P. Y }-85\end{array}$ & Spirulina labyrinthiformis & $\begin{array}{l}\text { 'Snake Pit' (hot spring), } \\
\text { Yellowstone National } \\
\text { Park, USA }\end{array}$ & $2 \mathrm{mS} \S$ & RWC & $\begin{array}{l}\text { Castenholz (1977, personal } \\
\text { communication) }\end{array}$ \\
\hline NIVA-CYA 163 & Spirulina subsalsa & $\begin{array}{l}\text { Atlantic Ocean, Oslofjord, } \\
\text { Drøbak, Norway\| }\end{array}$ & NA & $\mathrm{RS}$ & $\begin{array}{l}\text { Aakermann et al. (1992); } \\
\text { Rudi et al. (1997) }\end{array}$ \\
\hline NIVA-CYA 164 & Spirulina subsalsa & $\begin{array}{l}\text { Atlantic Ocean, Oslofjord, } \\
\text { Drøbak, Norway\| }\end{array}$ & NA & $\mathrm{RS}$ & $\begin{array}{l}\text { Aakermann et al. (1992); } \\
\text { Rudi et al. (1997) }\end{array}$ \\
\hline SAG B256.80 & 'Spirulina laxissima' & $\begin{array}{l}\text { Lake Nakuru (Natron } \\
\text { Lake), Kenya }\end{array}$ & NA & $\mathrm{EH}$ & Schlösser (1994) \\
\hline
\end{tabular}

NA, Information not available.

* Culture collections: ATCC, American Type Culture Collection, Manassas, VA, USA; CCAP, Culture Collection of Algae and Protozoa, Ambleside, UK. CCC, Castenholz Culture Collection, University of Eugene, OR, USA [the CCC has recently been consolidated with others and is now referred to as Culture Collection of Microorganisms from Extreme Environments (CCMEE), University of Eugene, OR, USA]; MPI, Max Planck Institute for Marine Microbiology, Bremen, Germany; NIVA, Culture Collection of Algae, Oslo, Norway; PCC, Pasteur Culture Collection, Paris, France; SAG, Sammlung von Algenkulturen, Göttingen, Germany; UBMM, University of Bremen, Marine Microbiology, Bremen, Germany. Designations given in parentheses indicate related strains.

$\uparrow$ Classification based on trichome morphology; with the exception of ' S. laxissima', generic names given are sensu Castenholz (1989a) and Anagnostidis \& Komárek (1988), and species epithets are sensu Anagnostidis \& Golubic (1966) and Geitler (1932).

$\$$ Researchers that isolated the cyanobacterial strains are abbreviated with their initials: M. M. Allen (University of California, Berkeley, CA, USA), R. W. Castenholz (University of Oregon, Eugene, OR, USA), E. Clavero (CID-CSIC, Barcelona, Spain), E. Hegewald (University of Göttingen, Germany), J. Rethmeier (University of Bremen, Germany), R. Skulberg (NIVA, Oslo, Norway), A. Wilmotte (University of Liege, Belgium).

$\S$ Conductivity.

\| In contrast to the given references, a seawater aquarium is quoted as the site of isolation in the NIVA catalogue of strains (Skulberg, 1990). 
Carotenoids were identified by cochromatography and spectroscopic matching with authentic primary or secondary standards. Details on the identification and quantification of carotenoids and sources of standards have been published previously (Karsten \& Garcia-Pichel, 1996). Phycobiliproteins were released from approximately $50 \mathrm{mg}$ cells (wet wt) into $20 \mathrm{mM}$ sodium acetate, $\mathrm{pH} 5.5$ (Tandeau de Marsac \& Houmard, 1988), after breaking the cells by repeated freezing and thawing (liquid nitrogen $/ 45^{\circ} \mathrm{C}$ ) and subsequent ultrasonication. Lysates were clarified by centrifugation in a microcentrifuge and the presence or absence of typical absorption or fluorescence corresponding to either phycoerythrin, phycoerythrocyanin or phycocyanin was determined.

PCR amplification, cloning and sequence analysis of $16 \mathrm{~S}$ rRNA genes. The molecular biological procedures used have been described in detail previously (Garcia-Pichel et al., 1998). Briefly, cells harvested by centrifugation and suspended in TE buffer $(10 \mathrm{mM}$ Tris $/ \mathrm{HCl}, \mathrm{pH} 8 \cdot 0,1 \mathrm{mM}$ EDTA) were directly applied as templates for PCR. To determine almost complete sequences of $16 \mathrm{~S}$ rRNA genes from cyanobacteria in unialgal but non-axenic cultures, primers 8F (Buchholz-Cleven et al., 1996) and 1528R (Garcia-Pichel et al., 1998) were used for PCR amplifications and the resulting PCR products were cloned applying the pGEM-T plasmid vector system (Promega). Full-length cyanobacterial 16S rRNA genes from plasmid inserts were reamplified using the same primers as before. To avoid errors due to PCR artifacts or operon microheterogeneities, PCR products derived from 10 different plasmids were mixed and processed for sequencing. For some strains only partial sequences (approx. $560 \mathrm{nt}$ ) were determined by applying cyanobacteria-specific primers CYA106F and CYA781R for amplification and sequencing (Nübel et al., 1997). Both DNA strands of the amplification products were sequenced as described previously (Garcia-Pichel et al., 1998 ) by using the primers 8F, 1099F, 1175R (BuchholzCleven et al., 1996), CYA106F, CYA359F, CYA781R (Nübel et al., 1997) and 1528R. All primer designations refer to $5^{\prime}$ ends of the respective target sites in the $16 \mathrm{~S}$ rRNA genes (Escherichia coli numbering of $16 \mathrm{~S}$ rRNA nucleotides; Brosius et al., 1981) and to forward (F) or reverse (R) orientation relative to that of the rRNA.

Phylogeny reconstruction. Cyanobacterial 16S rRNA gene sequences available from GenBank and those determined in this study were aligned to the sequences in the database of the software package ARB, developed by W. Ludwig and O. Strunk, and available at http://www.mikro.biologie.tumuenchen.de/. Phylogenetic trees were constructed on the basis of 73 almost complete sequences (from nt 45 to 1455 corresponding to $E$. coli numbering) [database accession nos of sequences used: Y18789, Y18790, Y18792, Y18793, AF091109, X75045, AB003164, AJ000716, 1001484, X52171, AF001480, AF053396-AF053399, AF001477, X03538, AJ007907, AF091110, AJ007374, AB003169, AB003163, X84810, X84808, Chms.sglbs (RDP), X84809, AJ000715, X78680, Z28699, AJ000708-AJ000714, AJ000724, X78681, Prcl.didem (RDP), AF013030, X70767, AF013028, AF013029, AF091321, AF091322, X70769, $\mathrm{X} 70770, \mathrm{X} 75044, \mathrm{X} 84811, \mathrm{X} 84812, \mathrm{Chrc.7203}$ (RDP), AF027653-AF027655, AF062637, AF062638, X59559, $\mathrm{X} 68780, \mathrm{AJ} 224447, \mathrm{AF} 067818, \mathrm{AF} 067819$, AF092504, AF091150, AB003165-AB003168, J01422, X82156, AF091108, Glb.violac(RDP), M24911, D26185]. Alignment positions at which one or more sequences had gaps or ambiguities were omitted from the analyses. To evaluate the consistency of computed tree topologies, subsets of data were analysed by using various algorithms as follows. A variety of single and multiple outgroup sequences representing phylogenetically diverse organisms were included in the analyses. To assess the influence of the most variable nucleotide positions they were excluded from some calculations by applying filters based on character frequency (see ARB manual; Ludwig et al., 1998). The maximumlikelihood, maximum-parsimony and neighbour-joining methods as integrated in the ARB software package were applied. The latter calculation was based on a matrix of evolutionary distances determined using the Jukes-Cantor or Felsenstein equations. The maximum-parsimony calculation was subject to bootstrap analysis (1000 replicates). In the dendrogram presented, partial sequences (database accession numbers: Y18791, Y18792, Y18794-Y18798, Z82787, Z82788) were integrated according to the maximum-parsimony criterion without allowing them to change the topology of the tree as established with complete sequences (see ARB manual;Ludwig et al., 1998).

\section{RESULTS}

\section{Microscopic observations}

Results of microscopic observations are summarized in Table 2. With the exception of 'Spirulina laxissima' SAG B256.80 all strains studied have regularly helically coiled trichomes, thin crosswalls invisible by light microscopy and no visible sheaths (Fig. 1). Thus, they fit the description of the genus Spirulina sensu Castenholz (1989a) and sensu Anagnostidis and Komárek (1988), and the 'section' Euspirulina of the genus Spirulina sensu Geitler (1932). Coiling is either clockwise or counter-clockwise depending on the respective strains. For all these strains, motility was observed as apparent rotation along the helix axis. In PCC 6313 and UBMM Hi 45, trichome coils are open, whereas in all other strains coils are closed (Fig. 1). Trichome and helix widths vary among strains, thus different species epithets could be assigned according to traditional classification (Table 1; Anagnostidis \& Golubic, 1966; Geitler, 1932). Morphological variability within strains was not noticeable during the present study, even when grown under different cultivation conditions. However, slight despiralization under unfavourable growth conditions has been described for two marine strains (strain P7, also included in this study, and strain A4; Wilmotte, 1991) and for field populations (Anagnostidis \& Golubic, 1966).

Trichomes of strain SAG B256.80, designated 'Spirulina laxissima' in the catalogue of strains of the SAG culture collection (Schlösser, 1994), are constricted at the easily discernable crosswalls. They are curved or loosely helical, but spirality is not regular; it has longer relative wavelength than in any of the other strains (Fig. 1). Motility was not observed. This strain differed from all other strains investigated in this study by maintaining buoyancy and growing suspended homogeneously in liquid medium, instead of adhering to glass walls of culture tubes or forming pellicles. The identification of this strain as $S$. laxissima West in 
Table 2. Morphologies and temperature requirements

\begin{tabular}{|c|c|c|c|c|c|}
\hline Strain & $\begin{array}{l}\text { Helix } \\
\text { shape }\end{array}$ & $\begin{array}{c}\text { Trichome } \\
\text { width }(\mu \mathrm{m}) *\end{array}$ & $\begin{array}{l}\text { Helix width } \\
\qquad(\mu \mathrm{m})^{*}\end{array}$ & $\begin{array}{r}\text { Sense of } \\
\text { coiling } \dagger\end{array}$ & $\begin{array}{c}\text { Temperature } \\
\text { requirement }\left({ }^{\circ} \mathrm{C}\right)\end{array}$ \\
\hline CCC Baja-95 Cl. $2^{\mathrm{T}}$ & Closed & $1 \cdot 5$ & $4 \cdot 0$ & $\mathrm{ccw}$ & $20-38$ \\
\hline СCC Ваја-95 Cl. 3 & Closed & $3 \cdot 0$ & $6 \cdot 0$ & $\mathrm{ccw}$ & $20-38$ \\
\hline MPI S3 & Closed & $2 \cdot 5$ & $5 \cdot 0$ & $\mathrm{ccw}$ & $20-40$ \\
\hline MPI S1 & Closed & $1 \cdot 0$ & $2 \cdot 0$ & $\mathrm{cw}$ & $15-35$ \\
\hline MPI S2 & Closed & $1 \cdot 7$ & $3 \cdot 0$ & $\mathrm{cw}$ & $10-35$ \\
\hline MPI S4 & Closed & $1 \cdot 5$ & $3 \cdot 0$ & $\mathrm{cw}$ & $10-35$ \\
\hline P7 & Closed & $1 \cdot 6$ & $2 \cdot 7$ & $\mathrm{cw}$ & $10-35$ \\
\hline NIVA-CYA 163 & Closed & $1 \cdot 5$ & $4 \cdot 0$ & $\mathrm{ccw}$ & NA \\
\hline NIVA-CYA 164 & Closed & $1 \cdot 5$ & $4 \cdot 0$ & $\mathrm{ccw}$ & NA \\
\hline UBMM Bo89 & Closed & $1 \cdot 7$ & $3 \cdot 0$ & $\mathrm{cw}$ & $10-25$ \\
\hline $\begin{array}{l}\text { IAM M-223 (IAM } \\
\text { M-183) } \$\end{array}$ & Closed & $1 \cdot 5$ & $3 \cdot 0$ & $\mathrm{cw}$ & NA \\
\hline CCC Snake P. Y-85 & Closed & $1 \cdot 5$ & $3 \cdot 0$ & $\mathrm{cw}$ & $35-45$ \\
\hline UBMM Hi 45 & Open & $1 \cdot 5$ & $4 \cdot 0$ & $\mathrm{ccw}$ & $10-35$ \\
\hline PCC 6313 & Open & $2 \cdot 0$ & $4 \cdot 5$ & $\mathrm{ccw}$ & $10-35$ \\
\hline SAG B256.80 & No helix & $1 \cdot 5$ & - & - & NA \\
\hline
\end{tabular}

NA, Information not available.

* Mean values of at least 20 trichomes.

$\dagger \mathrm{cw}$, clockwise; ccw, counter-clockwise.

\$Data are from Shihira-Ishikawa (1990). That paper contains an illustration and a general description of strain IAM M-183, which is closely related to strain IAM M-223, according to the IAM catalogue of strains (second edition, 1998).

the sense of Geitler (1932) is questionable. Geitler had assigned this morphospecies to his 'section' Euspirulina, encompassing helically coiled cyanobacteria with crosswalls that are invisible in living specimens.

\section{Salt requirements}

The dependence of growth rates on salinity is illustrated in Fig. 2. With respect to their salt requirements for growth, the strains can be assigned to three groups which correlate with the environmental conditions in the habitats from which they were isolated: freshwater, marine and hypersaline (see Table 1). The only freshwater strain available (CCC Snake-P. Y-85) tolerated $1.6 \%$ total salts, but died at marine salinity $(3 \cdot 2 \%)$. Marine strains were somewhat variable with respect to salinity optima and tolerances. Typically they grew with optimum rates at $3 \cdot 2 \%$ total salts (MPI S4, P7, UBMM Bo 89, UBMM Hi 45) or slightly higher (MPI S1, PCC 6313, 7\%) or lower (MPI S2, $1 \cdot 6 \%$ ). Strains PCC 6313 and UBMM Hi 45 were remarkable in that they did not show a distinct and narrow salinity optimum, but were able to grow with close to optimum rates in freshwater medium (BG11). Thus, they can be termed euryhaline. Strain MPI S1 tolerated a salinity of $10 \%$ but died at $13 \%$. In contrast, three strains from hypersaline environments at $25{ }^{\circ} \mathrm{C}$ grew at salinities from 1.6 (MPI S3) or $3.2 \%$ (CCC Baja-95 Cl. $2^{\mathrm{T}}$, CCC Baja-95 Cl. 3) to $16 \%$. In strain CCC Baja-95 Cl. $2^{\mathrm{T}}$, elevated temperature $\left(38^{\circ} \mathrm{C}\right)$ resulted in increased growth rates at high salinities and an increased upper salinity limit of growth $(20 \%)$. This temperature effect on halotolerance had previously been observed for some unicellular, extremely halotolerant cyanobacteria (Garcia-Pichel et al., 1998). Thus, the three latter strains were extremely euryhaline and were among the most halotolerant cyanobacteria that have been described, second only to some members of the Halothece cluster of unicellular, extremely halotolerant strains (Garcia-Pichel et al., 1998; MacKay et al., 1984; Reed \& Stewart, 1988).

\section{Temperature requirements}

The cyanobacterial strains analysed showed markedly different temperature requirements (Table 2). Strain CCC Snake P. Y-85 was isolated from a $50{ }^{\circ} \mathrm{C}$ site in a sulfidic freshwater hot spring (Castenholz, 1977, personal communication). In our experiments, it showed growth between 35 and $45^{\circ} \mathrm{C}$ and did not grow at $50{ }^{\circ} \mathrm{C}$. Natural populations of this organism showed an upper temperature limit of $51^{\circ} \mathrm{C}$ and maximum photosynthesis rates at $45^{\circ} \mathrm{C}$ (Castenholz, 1977). The strains that had shown the highest halotolerance (MPI S3, CCC Baja-95 Cl. 3, CCC Baja-95 Cl. $2^{\mathrm{T}}$ ) tolerated 40 or $38^{\circ} \mathrm{C}$, respectively, and did not grow at $15^{\circ} \mathrm{C}$ and below. Thus they displayed a slightly elevated temperature requirement compared to the normal- 


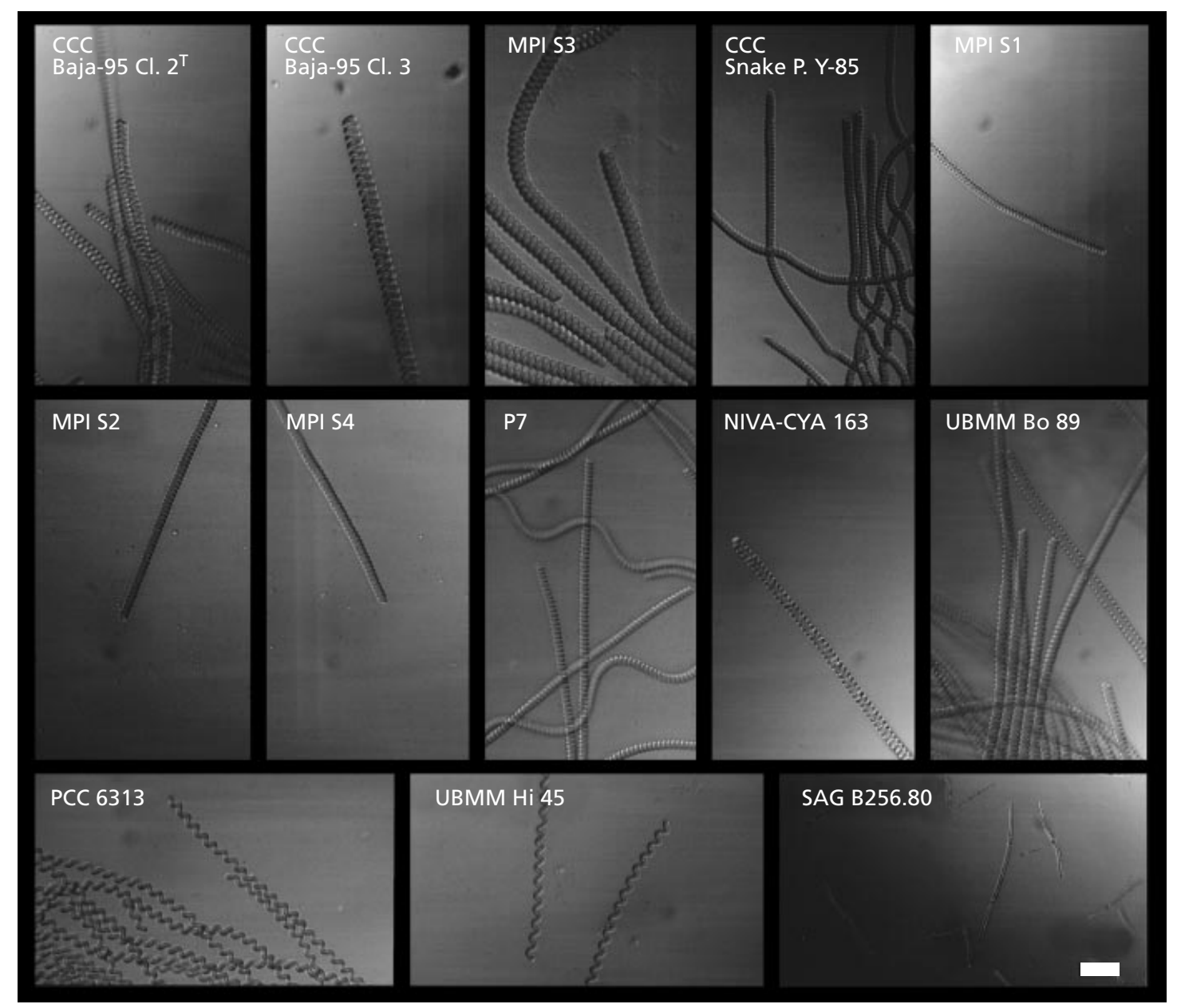

Fig. 1. Photomicrographs of cyanobacterial isolates. All organisms are shown at the same magnification and the bar shown applies to all panels. Bar, $10 \mu \mathrm{m}$.

salinity marine strains, most of which tolerated 10 $35^{\circ} \mathrm{C}$. Similarly, this characteristic was found in unicellular cyanobacteria from hypersaline environments and might be an adaptation to life in brines with low heat capacity which may easily reach high temperatures when sunlit (Castenholz, 1969; GarciaPichel et al., 1998).

\section{Pigment compositions}

All strains analysed contained phycocyanin. In addition, phycoerythin was detected in strains NIVACYA 164, P7 and UBMM Bo 89, while phycoerythrocyanin was not found in any strain. NIVACYA 164 had red trichomes and UBMM Bo89 had brownish to black trichomes, while all other strains looked blue-green when observed in white light. The ability for chromatic adaptation was not tested during this work; however, it has been reported to be lacking in strain P7 (Wilmotte, 1991) and in two red-pigmented strains A4 and 3F identified as Spirulina subsalsa status versicolor (Tomaselli et al., 1995; Wilmotte, 1991; Wilmotte et al., 1997).

With respect to their carotenoid contents, cyanobacteria with Spirulina-like morphology were rather diverse (Tables 3 and 4). The total number of carotenoids in the different strains varied from three to nine. $\beta$-Carotene was found in all strains and echinenone in most. Two of the most halotolerant strains (MPI S3, CCC Baja-95 Cl. 3) contained the same types of carotenoids in similar ratios; however, CCC Baja-95 Cl. $2^{\mathrm{T}}$ produced aphanyzophyll and an unidentified carotenoid with an absorption maximum at $480 \mathrm{~nm}$ instead of myxoxanthophyll (L-chinovosemyxol) and canthaxanthin. The carotenoid composition in the freshwater strain CCC Snake P. Y-85 and in the marine strains PCC 6313 and MPI S1 was found to be very similar. The phycoerythrin-producing strains NIVA-CYA 164, P7 and UBMM Bo 89 were different from each other with respect to their carotenoids. Strain NIVA-CYA 163 previously had been reported to contain considerable amounts of astax- 


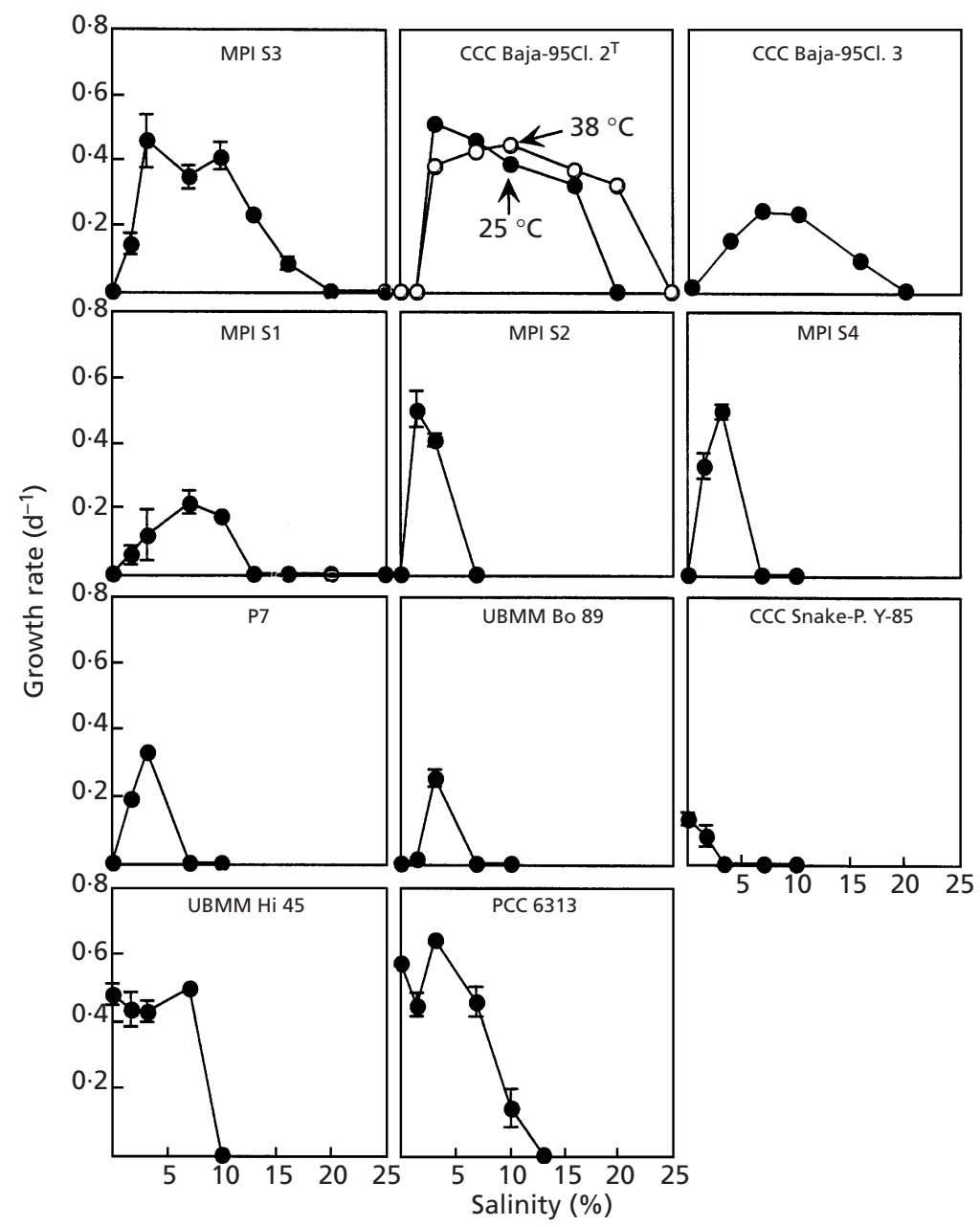

Fig. 2. Growth rates versus salinity in the cyanobacterial isolates investigated. All measurements were performed at $25^{\circ} \mathrm{C}$, except with strains CCC Snake P. Y- $85\left(38^{\circ} \mathrm{C}\right)$ and CCC Baja-95 Cl. $2^{\top}$ ( 25 and $38^{\circ} \mathrm{C}$ ).

Table 3. Retention time, absorption maxima and extinction coefficients $(\varepsilon)$ determined at $436 \mathrm{~nm}$ for the carotenoids detected

\begin{tabular}{|lccc|}
\hline Carotenoid & $\begin{array}{c}\text { Retention time } \\
(\mathbf{m i n})\end{array}$ & Absorption maxima* & $\boldsymbol{\varepsilon}\left(\mathbf{m M}^{\mathbf{- 1}} \mathbf{c m}^{\mathbf{- 1}}\right)$ \\
\hline Aphanyzophyll & $1 \cdot 37$ & $(452) 476506$ & \\
Myxoxanthophyll $\$$ & $3 \cdot 51$ & $(455) 478509$ & $69 \cdot 2 \dagger$ \\
Isozeaxanthin & $6 \cdot 04$ & $(430) 454481$ & $83 \cdot 2$ \\
Unknown carotenoid 1 & $6 \cdot 08$ & 480 & $143 \cdot 9 \dagger$ \\
Zeaxanthin & $7 \cdot 64$ & $(430) 454481$ & $83 \cdot 2$ \\
Canthaxanthin & $8 \cdot 45$ & 478 & $143 \cdot 9$ \\
Unknown carotenoid 2 & $8 \cdot 51$ & $(430) 448478$ & $83 \cdot 2 \dagger$ \\
Unknown carotenoid 3 & $9 \cdot 71$ & 467 & $143 \cdot 9 \dagger$ \\
Unknown carotenoid 4 & $14 \cdot 91$ & $(435) 453480$ & $83 \cdot 2 \dagger$ \\
Echinenone & $15 \cdot 11$ & $458(480)$ & $75 \cdot 3$ \\
$\beta$-Carotene & $19 \cdot 58$ & $(435) 453480$ & $125 \cdot 3$ \\
\hline
\end{tabular}

* Shoulders are given in parentheses.

$\dagger$ Extinction coefficients unknown and arbitrarily assigned on the basis of spectral resemblance to known carotenoids.

†L-Chinovose-myxol. 
Table 4. Carotenoid composition in cyanobacterial strains with Spirulina-like morphology

\begin{tabular}{|c|c|c|}
\hline Strain & $\begin{array}{l}\text { Total no. } \\
\text { carotenoids }\end{array}$ & Carotenoids identified* \\
\hline CCC Baja-95 Cl. $2^{\mathrm{T}}$ & 5 & Aphanyzophyll (2.05), UC1 (1.05), echinenone $(0 \cdot 81)$ \\
\hline CCC Baja-95 Cl. 3 & 5 & $\begin{array}{l}\text { Myxoxanthophyll }(0 \cdot 18) \text {, canthaxanthin }(1 \cdot 86) \text {, } \\
\text { echinenone }(0 \cdot 73)\end{array}$ \\
\hline MPI S3 & 7 & $\begin{array}{l}\text { Myxoxanthophyll }(0.50) \text {, canthaxanthin }(0.59) \text {, } \\
\text { echinenone }(0.50)\end{array}$ \\
\hline MPI S1 & 6 & $\begin{array}{l}\text { Myxoxanthophyll (1.05), canthaxanthin (1.00), UC3 } \\
(0 \cdot 14) \text {, echinenone }(0 \cdot 95)\end{array}$ \\
\hline MPI S2 & 5 & Myxoxanthophyll (0.38), isozeaxanthin $(2 \cdot 12)$, UC2 (0.46) \\
\hline MPI S4 & 3 & Isozeaxanthin $(1 \cdot 42)$ \\
\hline P7 & 6 & $\begin{array}{l}\text { Isozeaxanthin }(1 \cdot 36) \text {, zeaxanthin }(0 \cdot 36), \mathrm{UC} 2(0 \cdot 59), \mathrm{UC} 4 \\
(1 \cdot 41)\end{array}$ \\
\hline UBMM Bo89 & 3 & Isozeaxanthin $(0 \cdot 49), \mathrm{UC} 2(0 \cdot 12)$ \\
\hline UBMM Hi45 & 4 & Canthaxanthin (2.57), UC3 (0.29), echinenone (2.36) \\
\hline PCC 6313 & 6 & $\begin{array}{l}\text { Myxoxanthophyll }(0 \cdot 81) \text {, canthaxanthin }(1 \cdot 24) \text {, UC3 } \\
(0 \cdot 14) \text {, echinenone }(1 \cdot 14)\end{array}$ \\
\hline CCC Snake P. Y-85 & 5 & $\begin{array}{l}\text { Myxoxanthophyll }(0 \cdot 33) \text {, canthaxanthin }(1 \cdot 22), \text { UC3 } \\
(0 \cdot 11), \text { echinenone }(0 \cdot 41)\end{array}$ \\
\hline NIVA-CYA $163 \dagger$ & 9 & $\begin{array}{l}\text { Myxoxanthophyll }(0 \cdot 09) \text {, zeaxanthin }(1 \cdot 25) \text {, astaxanthin } \\
(0.56) \text {, echinenone }(0 \cdot 03)\end{array}$ \\
\hline NIVA-CYA $164 \dagger$ & 8 & $\begin{array}{l}\text { Myxoxanthophyll }(0 \cdot 02) \text {, zeaxanthin }(0 \cdot 44) \text {, echinenone } \\
(0 \cdot 02)\end{array}$ \\
\hline
\end{tabular}

* Molar amounts relative to $\beta$-carotene are given in parentheses. Carotenoids that made up less than $1 \%$ of the total were not identified. UC1, UC2, UC3 are unknown carotenoids 1, 2, and 3, respectively (see Table 3).

$\uparrow$ Data are from Aakermann et al. (1992); myxoxanthophyll contains an unknown portion of L-fucose-myxol.

anthin (Aakermann et al., 1992), which in these experiments was not detected in any other strain. Thus, from the data currently available, no obvious correlation of carotenoid composition and any other trait emerged. However, six strains that contained only small amounts of echinenone (NIVA-CYA 163, NIVA-CYA 164) or completely lacked this carotenoid (MPI S2, MPI S4, P7, UBMM Bo89) were of marine origin and clustered together in phylogenetic analyses based on 16S rRNA gene sequences (see below).

\section{$16 \mathrm{~S}$ rRNA gene sequences and phylogeny}

16S rRNA gene sequences were deposited in the EMBL database under accession numbers Y18789Y18798. A tree based on maximum-likelihood computation is illustrated in Fig. 3. Since phylogeny reconstruction applying the maximum-likelihood method is computationally very expensive, bootstrap values were determined based on maximum-parsimony (1000 replicates). The maximum divergence among 16S rRNA gene sequences from cyanobacteria with Spirulina morphology was found to be $9.4 \%$ $(11.3 \%$ as judged from partial sequences; not corrected for multiple base changes). The analyses unveiled three clusters of related sequences. 16S rRNA genes from the most halotolerant strains (MPI S3,
CCC Baja-95 Cl. 3, CCC Baja-95 Cl. $2^{\mathrm{T}}$ ) were $98 \cdot 6 \%$ or more similar to each other, $7.7 \%$ or more different from all other cyanobacteria and consistently clustered together in reconstructed phylogenetic trees regardless of the calculation methods applied and supported by results of bootstrap analysis. The second cluster encompassed six sequences from organisms of marine origin (P7, MPI S4, MPI S2, UBMM Bo 89, NIVACYA 163 , NIVA-CYA 164) that were $95.5 \%$ or more similar to each other. The third cluster contained the 16S rRNA gene sequences from the two strains with openly coiled trichomes (PCC 6313, UBMM Hi 45), which in the stretch analysed (nt 165-747; E. coli numbering) differed from each other by a single nucleotide insertion only. Applying various methods for tree calculations, all cyanobacteria with closed trichome coils consistently clustered together. PCC 6313 (together with UBMM Hi 45), however, either was positioned deeply branching from this cluster or was attracted by the node connecting Synechococcus sp. PCC 7002 and Oscillatoria sp. M-220 (not shown). The latter was the case when trees were calculated either on the basis of the maximum-parsimony algorithm or on the basis of distance matrices when nucleotide positions had been removed from the data sets that were conserved in less than $38 \%$ of the sequences in the respective alignments (Ludwig et al., 


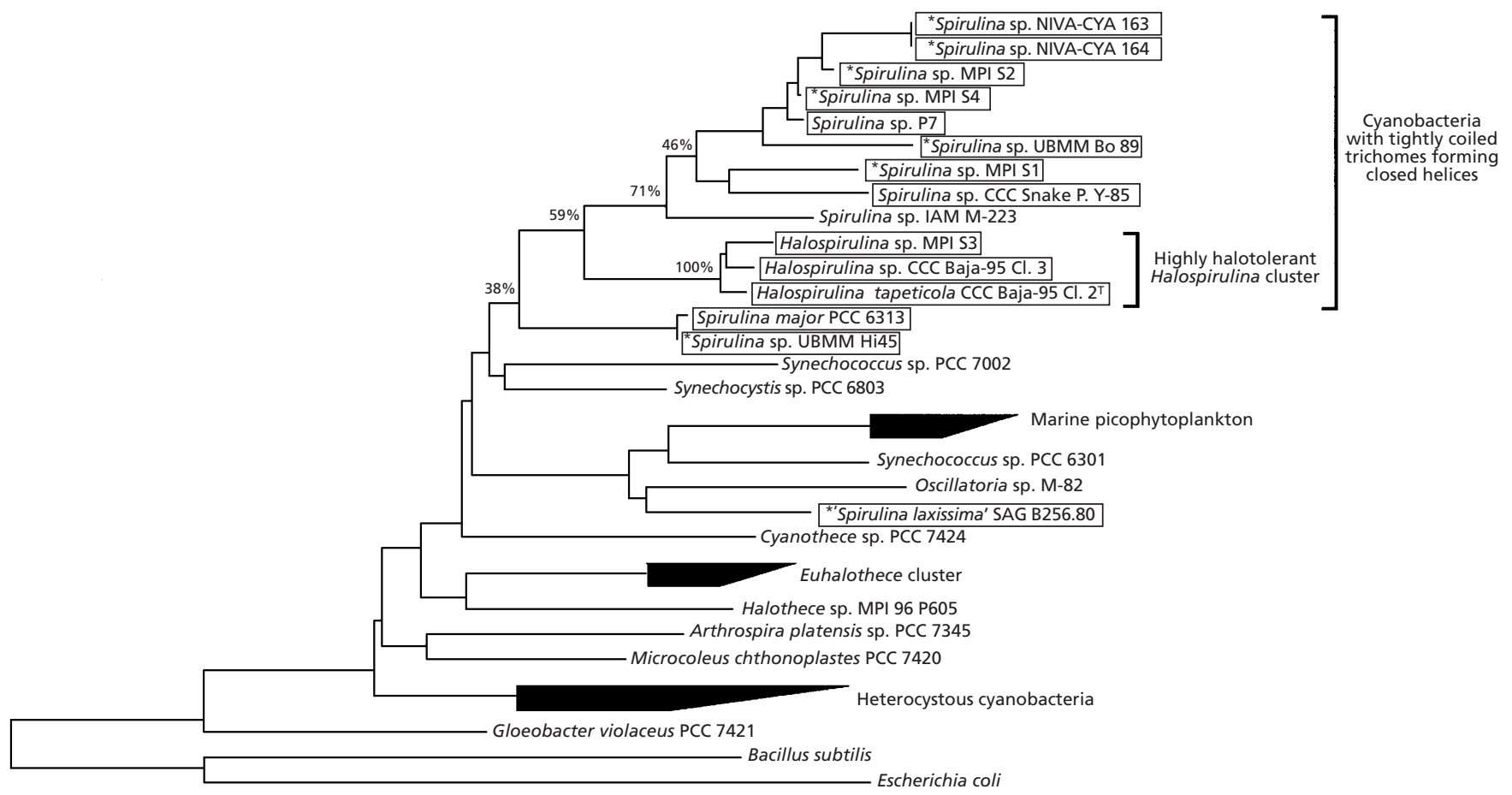

$0 \cdot 10$

Fig. 3. Maximum-likelihood phylogenetic tree based on $16 \mathrm{~S}$ rRNA gene sequences containing at least nt 45-1455 (E. coli numbering; Brosius et al., 1981). 16S rRNA gene sequences from $E$. coli and Bacillus subtilis were used as outgroup sequences. Bootstrap values were determined on the basis of maximum-parsimony calculations (1000 replicates), exclusively involving almost complete gene sequences. They are indicated only for those clusters that contain Spirulinalike cyanobacteria. The phylogenetic affiliations of organisms represented by partial sequences (strains are indicated by asterisks; partial sequences contain at least nt 170-746 or, in the case of strains NIVA CYA 163 and 164, nt 346-845; Rudi et al., 1997) were reconstructed by applying the parsimony criteria without changing the overall tree topology (see ARB manual; Ludwig et al., 1998). Strains investigated in this study are framed. The scale bar indicates $10 \%$ estimated sequence divergence.

1998). Strain SAG B256.80 ('Spirulina laxissima’) was not closely related to any other strain included in this study.

\section{DISCUSSION}

\section{Ecology, evolution and phylogeny}

Applying various methods for phylogeny reconstruction and including various subsets of $16 \mathrm{~S}$ rRNA gene sequence data, all trees computed assigned the cyanobacteria with closed trichome helices (i. e. excluding strains PCC 6313 and UBMM Hi 45) to a single cluster (Fig. 3). The genetic divergence among these strains nevertheless was unexpectedly high, with (almost complete) $16 \mathrm{~S}$ rRNA gene sequences differing by up to $9.4 \%$ (not corrected for multiple base changes at individual nucleotide positions), suggesting that Spirulina morphology is an early and stable development in the evolution of cyanobacteria. This hypothesis is in accordance with the observation of microfossils resembling these recent cyanobacteria which date back 850 million years (Schopf, 1996).
Strains PCC 6313 and UBMM Hi 45, representing cyanobacteria that are coiled more openly and thus would be identified as $S$. major according to morphology-based taxonomy (Fig. 1; Geitler, 1932; Rippka \& Herdman, 1992), seem to be only loosely affiliated to this cluster, however. Although it seems likely that all strains with open and closed trichome helices have a common ancestor, as suggested by the majority of phylogenetic trees calculated, bootstrap analysis failed to support this hypothesis. The short internodal branch in the phylogenetic tree (Fig. 3) indicates that the separation of this group from other cyanobacteria is based on information provided by only a few nucleotide positions (Ludwig et al., 1998). Thus, the indication of a monophyletic origin of all Spirulina-like strains is of only low significance and the possibility that Spirulina morphology evolved convergently in two separate lineages of cyanobacteria cannot be dismissed with confidence.

Spirulina-like strains able to grow at salinities of $13 \%$ and above were found to be closely related to each other independently of their geographic origin. Phylo- 
genetic analyses placed these three strains within a tight cluster clearly distinct from other cyanobacteria, including the extremely halotolerant, unicellular cyanobacteria (Fig. 3; Garcia-Pichel et al., 1998). Growth in hypersaline environments requires a number of adaptations. The ability to accumulate quaternary ammonium compounds as osmolites is probably very significant (Garcia-Pichel et al., 1998). Glycine betaine or glutamate betaine is produced by all cyanobacteria that are able to grow in brines with more than $13 \%$ salinity and has also been found in highly halotolerant strains displaying Spirulina morphology (Gabbay-Azaria \& Tel-Or, 1991; MacKay et al., 1984; Reed \& Stewart, 1988). Thus, the genetic divergence of these strains from their counterparts in freshwater and normal marine environments can be understood in terms of a separate evolutionary history based on the ecophysiological capability to exploit extreme environmental niches. Similar results were recently reported for unicellular cyanobacteria (Garcia-Pichel et al., 1998) and anoxygenic phototrophic bacteria of the families Chromatiaceae (Imhoff et al., 1998) and Ectothiorhodospiraceae (Imhoff \& Süling, 1996).

\section{Consequences for classification}

Our data disprove the traditional opinion of broad ecological euryvalence and ubiquitous distribution of few closely related species of cyanobacteria with Spirulina morphology (Anagnostidis \& Golubic, 1966). Ecologically distinct organisms thriving in different habitats have different physiological capabilities and different evolutionary histories that are reflected in genetic divergence. The sequence divergence among 16S rRNA genes from cyanobacteria currently assigned to the genus Spirulina (9.4\%, uncorrected) is significantly larger than that typical for genera of other prokaryotes (Amann et al., 1992; Ash et al., 1993; Vandamme et al., 1996; Wisotzkey et al., 1992). In addition, large differences in $G+C$ content of genomic DNA have been reported $(53.5 \mathrm{~mol} \%$ versus $43.8 \mathrm{~mol} \%$ in strains PCC 6313 and P7, respectively; Herdman et al., 1979; Wilmotte et al., 1997). This extent of genetic divergence is almost as large as that found among all heterocystous cyanobacteria so far investigated, the $16 \mathrm{~S}$ rRNA genes of which differ in sequence by a maximal $10.4 \%$ (our calculation) and the DNA compositions of which span 38-47 mol \% (Herdman et al., 1979). Nevertheless, cyanobacteria able to form heterocysts currently are classified as two different orders, Nostocales and Stigonematales (Anagnostidis \& Komárek, 1990; Castenholz, 1989b, c; Komárek \& Anagnostidis, 1989) with a total of 80 different genera (Anagnostidis \& Komárek, 1990; Komárek \& Anagnostidis, 1989). This discrepancy reflects a drastic underestimation of the genetic and physiological diversity of cyanobacteria by traditional morphology-based classification, especially when cyanobacteria with less complex morphologies are concerned. Obviously, the conspicuous shape of the cyanobacteria investigated in this study is evolutionarily too conserved to be an appropriate and sufficient taxonomic character for their classification at the genus level. Instead, to acknowledge the diversity of these micro-organisms, criteria are needed to define physiologically and phylogenetically coherent new taxa (Anagnostidis \& Komárek, 1988; Castenholz, 1992).

The differential salt requirements or tolerances of bacteria reflect their adaptations to different habitats and to separate evolutionary developments, and therefore, these characteristics are established as important criteria in bacteriological classification (Imhoff et al., 1998). For example, the specific salt response can be used to distinguish major phylogenetic branches of anoxygenic phototrophic bacteria (Imhoff et al., 1998). We have recently reported that unicellular cyanobacteria that grow with close to optimum rates at salinities of $15 \%$ or above form a single or possibly two phylogenetic lineages within the cyanobacterial radiation (Garcia-Pichel et al., 1998). Here we demonstrate that some cyanobacteria with Spirulina-like morphology that are able to grow at salinities of $13 \%$ or higher are closely related to each other, but are only distantly affiliated to their morphological counterparts from freshwater and moderate marine habitats and are clearly distinct from all other cyanobacteria from which 16S rRNA gene sequences are available. In addition, these strains are physiologically similar in that they are extremely euryhaline but unable to grow in freshwater medium and they tolerate relatively high temperatures (at least 38 or $40{ }^{\circ} \mathrm{C}$, respectively). We propose the separation of those strains from the genus Spirulina and the reassignment of highly halotolerant cyanobacteria with helically coiled trichomes to the new genus Halospirulina gen. nov., which can be defined on the basis of basic morphology and high halotolerance (see below). The three strains of this cluster display different helix diameters $(4-6 \mu \mathrm{m})$, have different carotenoids and their $16 \mathrm{~S}$ rRNA gene sequences differ by a maximal $1 \cdot 4 \%$.

Strains PCC 6313 and UBMM Hi 45 have openly coiled trichomes and thus are morphologically similar to each other and distinct from all other strains. Interestingly, these strains were the only ones included in this study that were euryhaline in that they tolerated freshwater as well as marine salinity. This is in accordance with the phylogenetic analysis based on 16S rRNA gene sequences, which places these strains separate and deeply branching from the cluster of cyanobacteria with tightly coiled trichomes in which single helix-turns touch each other (closed helices). PCC 6313 and UBMM Hi 45 match the morphologybased definition of Spirulina major Kützing ex Gomont (Anagnostidis \& Golubic, 1966; Geitler, 1932) which is the type species of the genus Spirulina according to the botanical code (lectotype; Castenholz, 1989a). If strain PCC 6313 would be accepted as the type strain for Spirulina major at the species and genus level as previously suggested (Rippka \& Herdman, 1992), then 
probably all other strains (except UBMM Hi 45) need to be reclassified and assigned to newly created genera. However, this is not the intention here and will require future studies. Additional physiological and genetic characters need to be investigated and the suitability of helix tightness as a taxonomic criterion needs to be confirmed. Possibly, morphological variability within strains may complicate the use of the latter since slight despiralization depending on growth conditions has been described (Wilmotte, 1991). Hindák (1985) even reported the occurrence of completely uncoiled filaments in a culture of $S$. major. Other studies on the variability of helix tightness, however, have been restricted to cyanobacteria that have to be assigned to the genus Arthrospira according to current classification (Hindák, 1985; Jeeji-Bai, 1985; Jeeji-Bai \& Seshadri, 1980; Lewin, 1985).

\section{Description of Halospirulina gen. nov.}

Halospirulina gen. nov. (Ha.lo.spi.ru.li'na. Gr. n. hals, halos salt; L. dim. fem. n. spirulina a small coil; N.L. fem. n. Halospirulina salt-tolerant small coil).

Halotolerant, euryhaline cyanobacteria with trichomes coiled into a tight, closed helix, able to grow at salinities between 3 and $13 \%$ or above, but not at freshwater salinities. Trichome widths are typically between 1.5 and $3 \mu \mathrm{m}$, and helix widths vary between 4 and $6 \mu \mathrm{m}$. The cross walls are thin and invisible in live specimens. No sheath is visible under light microscopy. Gliding motility present, involving rotation. Found in sunlit hypersaline environments. Tolerate temperatures for growth of at least $38{ }^{\circ} \mathrm{C}$. Type species is Halospirulina tapeticola.

\section{Description of Halospirulina tapeticola sp. nov.}

Halospirulina tapeticola sp. nov. (ta.pe.ti'co.la. L. n. tapete mat; L. suff. cola dweller; M.L. fem. n. tapeticola, microbial-mat dweller).

Halotolerant, euryhaline cyanobacteria with trichomes coiled into a tight, closed helix, able to grow at salinities between 3 and $20 \%$, but not at freshwater salinities. Trichome and helix widths are 1.5 and $4 \mu \mathrm{m}$, respectively. The cross walls are thin and invisible in live specimens. No sheath is visible under light microscopy. Gliding motility present, involving rotation. The axenic type strain is CCC Baja-95 $\mathrm{Cl} .2^{\mathrm{T}}$, which was isolated from a microbial mat in a hypersaline evaporation pond of a salina at the Pacific coast of Baja California, Mexico. This strain is available from the Culture Collection of Microorganisms from Extreme Environments, Eugene, OR, USA, as CCC Baja-95 Cl. $2^{\mathrm{T}}$, and has been deposited in the Pasteur Culture Collection, Paris, France.

\section{ACKNOWLEDGEMENTS}

We are indebted to E. Clavero, R. W. Castenholz and J. Rethmeier for their generous gifts of cyanobacterial strains and we thank A. Portwich for HPLC support. Helpful comments on earlier versions of this manuscript have been provided by R. W. Castenholz, E. Clavero and A. Wilmotte, and are greatly acknowledged. We thank H. G. Trüper for providing the etymology of Halospirulina. This work was financially supported by the Max Planck Society and the Deutsche Forschungsgemeinschaft.

\section{REFERENCES}

Aakermann, T., Skulberg, O. M. \& Liaaen-Jensen, S. (1992). A comparison of the carotenoids of strains of Oscillatoria and Spirulina (Cyanobacteria). Biochem Syst Ecol 20, 761-769.

Amann, R. I., Lin, C., Key, R., Montgomery, L. \& Stahl, D. A. (1992). Diversity among Fibrobacter isolates: towards a phylogenetic classification. Syst Appl Microbiol 15, 23-31.

Anagnostidis, K. \& Golubic, S. (1966). Über die Ökologie einiger Spirulina-Arten. Nova Hedwigia 11, 309-335.

Anagnostidis, K. \& Komárek, J. (1988). Modern approach to the classification system of cyanophytes 3. Oscillatoriales. Arch Hydrobiol Suppl 80, 327-472.

Anagnostidis, K. \& Komárek, J. (1990). Modern approach to the classification system of cyanophytes 5. Stigonematales. Algol Stud 59, 1-73.

Ash, C., Priest, F. G. \& Collins, M. D. (1993). Molecular identification of rRNA group 3 bacilli (Ash, Farrow, Wallbanks, and Collins) using a PCR probe test. Antonie Leeuwenhoek 64, 253-260.

Brosius, M., Dull, T., Sleeter, D. D. \& Noller, H. F. (1981). Gene organization and primary structure of a rRNA operon from Escherichia coli. J Mol Biol 148, 107-127.

Buchholz-Cleven, B. E. E., Rattunde, B. \& Straub, K. L. (1996). Screening for genetic diversity of isolates of anaerobic Fe(II)oxidizing bacteria using DGGE and whole-cell hybridization. Syst Appl Microbiol 20, 301-309.

Castenholz, R. W. (1969). Thermophilic blue-green algae and the thermal environment. Bacteriol Rev 33, 476-504.

Castenholz, R. W. (1977). The effect of sulfide on the blue-green algae of hot springs. II. Yellowstone National Park. Microb Ecol 3, 79-105.

Castenholz, R. W. (1989a). Oxygenic photosynthetic bacteria, group I. Cyanobacteria, subsection III. Order Oscillatoriales. In Bergey's Manual of Systematic Bacteriology, pp. 1771-1780. Edited by M. P. Bryant, N. Pfennig \& J. G. Holt. Baltimore: Williams \& Wilkins.

Castenholz, R. W. (1989b). Oxygenic photosynthetic bacteria, group I. Cyanobacteria, subsection IV. Order Nostocales. In Bergey's Manual of Systematic Bacteriology, pp. 1780-1793. Edited by M. P. Bryant, N. Pfennig \& J. G. Holt. Baltimore: Williams \& Wilkins.

Castenholz, R. W. (1989c). Oxygenic photosynthetic bacteria, group I. Cyanobacteria, subsection V. Order Stigonematales. In Bergey's Manual of Systematic Bacteriology, pp. 1794-1799. Edited by M. P. Bryant, N. Pfennig \& J. G. Holt. Baltimore: Williams \& Wilkins.

Castenholz, R. W. (1992). Species usage, concept, and evolution in the cyanobacteria (blue-green algae). J Phycol 28, 737-745.

Cohen, Z. \& Vonshak, A. (1991). Fatty acid composition of Spirulina and Spirulina-like cyanobacteria in relation to their chemotaxonomy. Phytochemistry 30, 205-206.

Dubinin, A. V., Gerasimenko, L. M. \& Zavarzin, G. A. (1995). Ecophysiology and species diversity of cyanobacteria from 
Lake Magadi. Microbiology (English translation of Mikrobiologiya) 64, 717-721.

Ehrlich, A. \& Dor, I. (1985). Photosynthetic micro-organisms of the Gavish Sabkha. In Hypersaline Ecosystems. Edited by G. M. Friedman \& W. E. Krumbein. Berlin \& Heidelberg: Springer.

Ferris, M. J., Ruff Roberts, A. L., Kopczynski, E. D., Bateson, M. M. \& Ward, D. M. (1996). Enrichment culture and microscopy conceal diverse thermophilic Synechococcus populations in a single hot spring microbial mat habitat. Appl Environ Microbiol 62, 1045-1050.

Gabbay-Azaria, R. \& Tel-Or, E. (1991). Regulation of intracellular $\mathrm{Na}^{+}$content during $\mathrm{NaCl}$ upshock in the marine cyanobacterium Spirulina subsalsa cells. Bioresour Technol 38, 215-220.

Garcia-Pichel, F., Mechling, M. \& Castenholz, R. W. (1994). Diel migrations of micro-organisms within a benthic, hypersaline mat community. Appl Environ Microbiol 60, 1500-1511.

Garcia-Pichel, F., Prufert-Bebout, L. \& Muyzer, G. (1996). Phenotypic and phylogenetic analyses show Microcoleus chthonoplastes to be a cosmopolitan cyanobacterium. Appl Environ Microbiol 62, 3284-3291.

Garcia-Pichel, F., Nübel, U. \& Muyzer, G. (1998). The phylogeny of unicellular, extremely halotolerant cyanobacteria. Arch Microbiol 169, 469-482.

Geitler, L. (1932). Cyanophyceae. In Rabenhorsts Kryptogamenflora von Deutschland, Österreich und der Schweiz. Leipzig: Akademische Verlagsgesellschaft (reprinted, Johnson Reprint Co., New York, 1971).

Herdman, M., Janvier, M., Waterbury, J. B., Rippka, R. \& Stanier, R. Y. (1979). Deoxyribonucleic acid base composition of cyanobacteria. J Gen Microbiol 111, 63-71.

Hindák, F. (1985). Morphology of trichomes in Spirulina fusiformis Voronichin from Lake Bogoria, Kenya. Arch Hydrobiol Suppl 71, 201-218.

Hiraishi, A. \& Ueda, Y. (1994). Intrageneric structure of the genus Rhodobacter: transfer of Rhodobacter sulfidophilus and related marine species to the genus Rhodovulvum gen. nov. Int J Syst Bacteriol 44, 15-23.

Imhoff, J. F. \& Süling, J. (1996). The phylogenetic relationship among Ectothiorhodospiraceae: a re-evaluation of their taxonomy on the basis of 16S rDNA analyses. Arch Microbiol 165, $106-113$

Imhoff, J. F., Süling, J. \& Petri, R. (1998). Phylogenetic relationships among the Chromatiaceae, their taxonomic reclassification and description of the new genera Allochromatium, Halochromatium, Isochromatium, Marichromatium, Thiococcus, Thiohalocapsa and Thermochromatium. Int J Syst Bacteriol 48, 1129-1143.

Ishida, T., Yokota, A. \& Sugiyama, J. (1997). Phylogenetic relationships of filamentous cyanobacterial taxa inferred from 16S rRNA sequence divergence. J Gen Appl Microbiol 43, 237-241.

Jeeji-Bai, N. (1985). Competitive exclusion or morphological transformation? A case study with Spirulina fusiformis. Arch Hydrobiol Suppl 71, 191-199.

Jeeji-Bai, N. \& Seshadri, C. V. (1980). On coiling and uncoiling of trichomes in the genus Spirulina. Arch Hydrobiol Suppl 60, $32-47$.

Karsten, U. \& Garcia-Pichel, F. (1996). Carotenoids and mycosporine-like amino acid compounds in members of the genus Microcoleus (cyanobacteria): a chemosystematic study. Syst Appl Microbiol 19, 285-294.

Karsten, U., Klimant, I. \& Holst, G. (1996). A new in vivo fluorimetric technique to measure growth of adhering phototrophic micro-organisms. Appl Environ Microbiol 62, 237-243.

Komárek, J. \& Anagnostidis, K. (1989). Modern approach to the classification system of cyanophytes 4. Nostocales. Arch Hydrobiol Suppl 82, 247-345.

Kruschel, C. \& Castenholz, R. W. (1998). The effect of solar UV and visible irradiance on the vertical movements of cyanobacteria in microbial mats of hypersaline waters. FEMS Microbiol Ecol 27, 53-72.

Lewin, R. A. (1985). Uncoiled variants of Spirulina platensis (Cyanophyceae: Oscillatoriaceae). Arch Hydrobiol Suppl 60, $48-52$

Ludwig, W., Strunk, O., Klugbauer, S., Klugbauer, N., Weizenegger, M., Neumaier, J., Bachleitner, M. \& Schleifer, K. H. (1998). Bacterial phylogeny based on comparative sequence analysis. Electrophoresis 19, 554-568.

MacKay, M. A., Norton, R. S. \& Borowitzka, L. J. (1984). Organic osmoregulatory solutes in cyanobacteria. J Gen Microbiol 130, 2177-2191.

Nelissen, B., Wilmotte, A., Neefs, J.-M. \& De Wachter, R. (1994). Phylogenetic relationships among filamentous helical cyanobacteria investigated on the basis of $16 \mathrm{~S}$ rRNA gene sequence analysis. Syst Appl Microbiol 17, 206-210.

Nübel, U., Garcia Pichel, F. \& Muyzer, G. (1997). PCR primers to amplify $16 \mathrm{~S}$ rRNA genes from cyanobacteria. Appl Environ Microbiol 63, 3327-3332.

Overmann, J. \& Tuschak, C. (1997). Phylogeny and molecular fingerprinting of green sulfur bacteria. Arch Microbiol 167, 302-309.

Pentecost, A. (1994). Formation of laminate travertines at Bagno Vignone, Italy. Geomicrobiol J 12, 239-251.

Reed, R. H. \& Stewart, W. D. P. (1988). The responses of cyanobacteria to salt stress. In Biochemistry of the Algae and Cyanobacteria, pp. 217-231. Edited by L. J. Rogers \& J. R. Gallon. Oxford: Clarendon Press.

Rethmeier, J. (1995). Untersuchungen zur Ökologie und zum Mechanismus der Sulfidadaption mariner Cyanobakterien der Ostsee. $\mathrm{PhD}$ thesis, University of Bremen.

Rippka, R. \& Herdman, M. (1992). Pasteur Culture Collection of Cyanobacterial Strains in Axenic Culture. Catalogue and Taxonomic Handbook. Paris: Institut Pasteur.

Rippka, R., Deruelles, J., Waterbury, J. B., Herdman, M. \& Stanier, R. Y. (1979). Generic assignments, strain histories and properties of pure cultures of cyanobacteria. J Gen Microbiol 111, 1-61.

Rudi, K., Skulberg, O. M., Larsen, F. \& Jakobsen, K. S. (1997). Strain characterization and classification of oxyphotobacteria in clone cultures on the basis of $16 \mathrm{~S}$ rRNA sequences from the variable regions V6, V7, and V8. Appl Environ Microbiol 63, 2593-2599.

Schlösser, U. G. (1994). SAG-Sammlung von Algenkulturen at the University of Göttingen - Catalogue of strains 1994. Bot Acta 107, 113-186.

Schopf, J. W. (1996). Cyanobacteria: pioneers of the early Earth. Nova Hedwigia 112, 13-32.

Shihira-Ishikawa, I. (1990). Characteristic structures of Spirulina trichome involved in gliding movement. Plant Morphol 2, 7-14.

Skulberg, O. M. (1990). NIVA. Culture Collection of Algae. Oslo: Norwegian Institute for Water Research. 
Starr, R. \& Zeikus, J. (1987). UTEX - the culture collection of algae at the University of Texas at Austin. $J$ Phycol 23, 1-47.

Tandeau de Marsac, N. \& Houmard, J. (1988). Complementary chromatic adaptation: physiological conditions and action spectra. Methods Enzymol 167, 318-328.

Tomaselli, L., Margheri, M. C. \& Sacchi, A. (1995). Effects of light on pigments and photosynthetic activity in a phycoerythrin-rich strain of Spirulina subsalsa. Aquat Microb Ecol 9, 27-31.

Tomaselli, L., Palandri, M. R. \& Tredici, M. R. (1996). On the correct use of the Spirulina designation. Algol Stud 83, 539-548.

Tseng, C.-T. \& Chang, T.-P. (1990). Ultrastrukturen von vier 'Spirulina'-Arten. Algol Stud 60, 33-41.

Turpin, P. J. F. (1829). Spiruline oscillarioide. In Dictionnaire des Sciences Naturelles. Paris: F. G. Lévrault.

Vandamme, P., Pot, B., Gillis, M., Vos, P. D., Kersters, K. \& Swings,
J. (1996). Polyphasic taxonomy, a consensus approach to bacterial systematics. Microbiol Rev 60, 407-438.

Wilmotte, A. (1991). Taxonomic study of marine oscillatoriacean strains (Cyanophyceae, Cyanobacteria) with narrow trichomes. I. Morphological variability and autecological features. Algol Stud 64, 215-248.

Wilmotte, A., Stam, W. \& Demoulin, V. (1997). Taxonomic study of marine oscillatorian strains (Cyanophyceae, Cyanobacteria) with narrow trichomes. III. DNA-DNA hybridization studies and taxonomic conclusions. Algol Stud 87, 11-28.

Wisotzkey, J. D., Jurtshuk, P. J., Fox, G. E., Deinhard, G. \& Poralla, K. (1992). Comparative sequence analysis of the $16 \mathrm{~S}$ rRNA (rDNA) of Bacillus acidocaldarius, Bacillus acidoterrestris and Bacillus cycloheptanicus and proposal for the creation of a new genus, Alicyclobacillus gen. nov. Int $J$ Syst Bacteriol 42, 263-269. 